\title{
教育セミナー(4)＼cjkstart夢と抱負を語る(2)
}

\author{
司会のことば \\ 市村 恵一 \\ 医療法人友志会＼cjkstart石橋総合病院
}

本企画のすばらしさにまず敬意を表したい。従来、新任教授の抱負、教室運営方針については商業誌に一部が載って いただけで、学会が関与した試みは私の 42 年間の耳鼻咽喉科医生活の中では初めてである。新任教授として赴任する と。選ばれたものというほまれ意識とともに責任の重さを自覚し、教室をこう作り替えていきたいという抱負を現実の ものとして実現したいという意識が生まれる。教授就任後、少しずつ慣らし運転を始め、立場に慣れ、そろそろこれで 行けるという実感が出てくるのが就任 $2 、 3$ 年目であるが、この時期はまだ初心が失われていない。今回発表していた だける教授たちはまさにこの時期に当たり、「夢と抱負を語る」のに適した方々である。改めて村上会長の企画力には 畏れ入ったと率直に讃えたい。

大学教員は自分の教室・講座の教授の抱負を聞くことはあっても、他大学教授のそれを聞く機会はない。それだけで

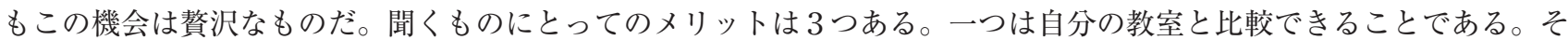
れにより、自教室の得意分野、弱点の再確認ができるし、改めてその構成員としての自覚が生じる。次に他教室の状況 を把握することにより、そことの交流（国内留学、研修会への参加、手術見学など）の契機となることである。最後 は、純粋に他人が夢を語るのを楽しめることである。もう開業されたり、病院の責任者で一本立ちされたりしている 方々の場合は最後だけが該当するかもしれない。私もそうであり、純粋に楽しみたいが、もう一つ、メリットではない が反省の念を含めて、自らの経験と比較するという作業が加わる。振り返ると私にも教授就任時には抱負があった。信 条として、自らの夢を学生や教室員の前で語ること、知識を得ることの面白さに気づきそれに邁進している人達に対し て雲囲気作り、場所作りをしてやることを自分に課した上で、毎年、年初にあたり基本方針を示していた。しかし、そ れがいつの間にか途中から中断してしまった。退任した今となっては、全体としてこそ達成感があるが、当初目標とし た個々の点についてやり残したことも多く、忸怩たる思いも残る。

堺屋太一氏によれば、「よい組織」というのに 3 要素があるという。「大きな」組織、「強い」組織、「堅い」組織であ る。組織は機能集団という面と共同体という面を併せ持つ。「大きさ」からいうと、確かに「大きい」方が立派にみえ る。しかし、「大きい」ということが本当にいいことなのかは現状では見直されなければならない。大学の講座の規模 もさまざまであり、いろいろな大きさに応じた運営法がある。ただ、組織は放置すれば自己肥大化する運命にある。そ の場合、大きさに応じてシステムを変えていく必要があるが、歴史の重み、中での住みやすさ、慣れなどからできるだ け現状を維持しようという組織防衛のための動きが出てくるし、その風潮が強くなると腐敗する。「強さ」は機能集団 としての外に対する影響力を指す。医療においては情報の発信力、診療成績の卓抜さ、研究成果の豊かさなどが該当す る。「堅さ」というのは共同体社会において、その中にいれば居心地がよい、過ごしやすいという状況を作ることだ。 これがなければ組織の運営が円滑にいかないため大事な要素ではあるが、これが最優先になるものではない。生き残れ ない組織は、大きさと堅さは着実に得るものの、強さが伴わない結果といえる。各教授が今回示された抱負を実現でき るよう邁進され、組織としての講座運営においてはぜひ「強さ」を前面に出して、新たなもの、よいものをほかに向け て発信する義務を果たしていただきたいと心から望むものである。 


\title{
横浜市立大学における耳鼻咽喉科医の育成
}

\author{
折舘 伸彦 \\ 横浜市立大学 医学部 耳鼻咽喉科・頭頸部外科学
}

私は着任当初「近視眼的な業績を追うことなく、次世代の耳鼻咽喉科・頭頸部外科学領域の発展を担う人材を育てた い」と考えておりました。今もその信念に変わりはありませんが、横浜市立大学の中で 3 年間を過ごして、その目標は より現実味を帯びたものになっていると思います。その理由は横浜市立大学が医学部を持つ県内唯一の公立大学である ため、横浜市そして神奈川県の医療に責任を持ち、地域医療に貢献するという義務があるという事害と密接に関連して います。横浜市民370万人が横浜市立大学附属 2 病院に求めるニーズは非常に高いものがあります。一方で横浜市立大 学の臨床各科への新入医局員の合計は毎年200人を超え、横浜市民からのニーズに応えようとして手をあげる人も多い という現実もあります。つまり横浜市立大学が目指す都市型地域医療を担う人材の育成については需給のバランスが高 いレベルで保たれている状態といえます。そのような状況下では、実地臨床医の育成はもちろんのこと、Physician一 Scientist（「研究医」と訳されることが多いようです）や基礎医学を志す研究者の育成も可能であることを私はこの 3 年間に体感してきました。実際、横浜市立大学先端医科学研究センターでは、研究拠点形成に向けた国の大型研究プロ ジェクトが複数採択されており、基礎研究分野で大きな成果を上げています。このような状況を耳鼻咽喉科・頭頸部外 科学の「次世代を担う人材を育てる」という目標に当てはめて考えてみれば、医療の進歩に応じた知識・医療技能を持 つ耳鼻咽喉科専門医を養成して地域医療に貢献することを第一ステップとし、その志を持って集まってくれる若手医師 たちの中から、科学的思考のできる臨床医・研究医を育成することを次のステップとすることになるのではないでしょ うか。事実、私はそのような方向性に手応えを感じています。現実との折りあいを重視して、与えられた環境でのべス トパフォーマンスを追求していく step by step 方式によって横浜市立大学の発展と耳鼻咽喉科・頭頸部外科学の進歩に 貢献することが「夢」であり「抱負」であるといえると思います。 


\title{
就任後 3 年を経験して
}

\author{
小島 博己 \\ 東京慈恵会医科大学耳鼻咽喉科
}

今回はちょうど就任後 3 年を経過した時期であり、これまでの教室運営の検証の節目にあたる。そこでまず教室員に 対して満足度調査を施行した。アンケートの内容は勤務体制、subspecialty、適度な症例を担当できたか、将来の希 望、在籍希望年数から給料に至るまで多岐にわたる。今回これらの結果の一部を発表し、普段みえてこない現況を少し でも多く把握しつつ今後の運営につなげたいと考えている。

1. 臨床

基本的にすべての分野に対して質の高い医療を提供するということを第一目標としている。鼻科学、耳科学、頭頸部 外科学、口腔咽頭など多岐にわたる診療はそれぞれ各エキスパートの責任者に任せ、私は全体を統一するスタンスで診 療、研究を行っている。

専門分野である耳科学に限って言えば、まず中耳手術のさらなる充実が必要である。これには今まで以上に人工内耳・ 人工中耳などの人工聴覚器を含めたあらゆるニーズに対応できるよう体制の整備に努めたい。また頭蓋底手術に対して もより広範囲な病変に対して確実かつ安全な手術が行えるよう準備をしている。さらに小児に対する専門外来の設置な ど、今後のニーズに向けた専門外来の再整備も考えている。

2. 研究

現在中耳粘膜の再生をテーマに研究を進めている。鼻粘膜シートの中耳腔への移植はすでに臨床研究の段階に入り、 良好な成績を収めているが、今後はさらなる成績向上と改良を目指している。最終的には治験が行えるような環境を整 えたい。また真珠腫の成因に対しては本多、森山教授時代からの継続した教室のテーマであり、継続した研究を行って いる。また真珠腫の手術に関してはスタンダードな術式がなく、「EBMに基づいた真珠腫治療」を目指し、術式選択 に関する臨床研究について重点的に行う。

一方、従来弱かった分野である内耳の基礎研究について現在人的投入を行っている。内耳発生・再生の分野で貢献で きるような研究体制を作りたいと思っている。

\section{3. 教育}

当面は新専門医制度への対応が最も重要な事項となる。専攻医に対しては適切で満足のいく研修プログラムを提供 し、プログラム終了後の専門医認定をスムーズに行えることが必要である。プログラムには当教室の特長をだし、より 多くの専攻医を教育したいと考えている。当教室では数年前より「手術の見える化」を行っており、今後専攻医の症例 登録と連動させていく。

専門医取得後は subspecialty を尊重し、各分野でのエキスパートを育てていくことが大切であり、このことが次世代 の教育につながると考える。継続性のある人材の育成こそが教室員の教育の質の担保につながると考える。また専門医 試験も確実に合格しないと、専攻医の応募人数が減ることになり、これを避けるためにも専攻医の教育は従来よりもそ の重要性が増す。

\section{4. 教室運営}

教室運営で欠かせないことは教室員の確保である。従来は人数さえいれば関連病院を含めた人事配置は比較的スムー ズに行うことができた。新専門医制度により、指導医の数と配置が教室人事に影響をあたえ、より複雑なものになる。 地域貢献は大学にとって責務の一つであるが、指導医を確保できない病院は関連病院から外れることになり、これを回 避しなければ地域医療が崩壊してしまう。そのためには指導医の育成が大切なことは言うまでもない。指導医に必要な 症例数の確保や論文や学会発表が適切になされているかの確認なども教室全体で調整しなければならず事務的負担は相 当なものになる。一方で指導医に対してのインセンティブがないことは、指導医を継続するモチべーションを損ないか ねず、教室に残る魅力を提供していかなければならない。

\section{5. 将来展望}

耳鼻咽喉科の取り扱う疾患は多岐に渡り、また多くの境界領域を含む。一方で主に慢性炎症をターゲットに手術を行 っている診療科はまれである。腫瘍や外傷をのぞけば慢性副鼻腔炎、慢性中耳炎の手術の占める割合は非常に多い。小 児期の急性中耳炎の減少により単純穿孔性中耳炎が減少してきたことは周知の事実であるが、ワクチン接種などにより 今後さらに症例数が減ってくることは避けられない。真珠腫性中耳炎は炎症だけがその成因ではないと考えられるが、 それでも中耳手術を行う症例は減少するであろう。また慢性副鼻腔炎も時代とともに古典的ないわゆる蓄膿症から好酸 球性副鼻腔炎に代わってきており、厚労省の難病指定に選ばれたばかりであるが、この疾患は全身性疾患であるがゆえ に、喘息やアレルギーに対する薬剤の進歩とともに手術療法が次第に過去のものになる可能性が高い。このように10年 
後、20年後を見据えた耳鼻咽喉科診療を考え、今のうちから準備をしなければならない。

また医学だけでなく、ほかの産業の次世代キーワードを敏感に読み取り、反応する必要がある。間違いなくその一つ にあげられるのは第 3 の産業革命と呼ばれる AI（人工知能）である。身近なところでは自動車の完全自動運転がある が、これは数年以内に一般化することは間違いない技術革新である。自動運転には認識、判断、制御という3つのプロ セスが必要になる。また道路情報など極めて大きなビッグデータの蓄積・解析が不可欠であり、これが従来の自動車メ 一カーよりもデータベースを保有しているIT 企業が自動運転に早くから参加している理由である。ビッグデータの解 析、特に認識の部分で AI が多いに活躍する。手術に置き換えてみるだけでも自動運転で必要なこの 3 つの要素はほぼ 共通したものであり、臨床のビッグデータの蓄積・解析によりロボット工学と合わせて将来の柱になることは間違いな い。アナログ時代の私はこのような傾向を決して歓迎はしないが、好き嫌いにかかわらず、時代の流れであるので今か ら着手しなければならない。これには単なる理工学部との共同研究や産学連携といった従来のレベルではとても対応で きず、少なくとも学会レベルでの活動が必要である。医学とは全く無縁であった IT 産業が次世代のマーケットとして 医療に本格的に参入する前に All Japan でAI を上手く応用していく必要性が目の前に来ている。 
Our Mission: Possible

西野宏

自治医科大学医学部

\section{私の夢は「人類の発展に寄与する医学と医療を築き、歩みを刻む」ことである。これを実現するための抱負としての目 標を述べたい。}

\section{講座はキャンバスに描かれた印象派の画}

医療と医学はアートとしてたとえられることがある。画は観る人に感動と影響を与え、後世の発展に寄与する。刻々 と変化する光の変化を捉えた印象派画派の画に人々は心を動かされる。その夕ッチをよく観ると、独立した色々な色彩 のタッチが融合して見事な調和した色彩の変化を表現している。講座の運営もまた同様と考える。一人一人の唯一無二 の個性の特性を伸ばし、その個性が融合した調和を表現しなくてはならない。耳鼻咽喉科学は耳科学、鼻科学、音声、 頭頸部癌等多岐の領域にわたる。お互いに影響をおよぼしい進歩させなければならない。

\section{内なる悪魔に打ち勝つ}

高度に進歩した医学に対する医師の倫理が未熟な現代が存在する。生命倫理の道を踏み外した幾つかの事例の反省よ り、各組織において倫理講習会が盛んに行われ始めた。何よりも大切なことは、一人一人の医師が生命倫理を理解し実 践することである。しかし人間の理性は強いものではない。理性と誘惑がせめぎ合う。困難に直面した時に悪魔が出現 し、甘いささやきをするかもしれない。この悪魔のささやきから救い出してくれるのは仲間である。組織として助け合 って行かなければならない。専攻医の教育に mentorを導入したい。ヒポクテラスの誓いと世界医師会総会におけるジ ユネーブ宣言の原点に戻り、人類の発展に寄与する医学と医療を築かなければならない。

\section{三つ子の魂百まで}

自治医科大学は、医療に恵まれないへき地等における医療の確保と向上および地域住民の福祉の増進を図る目的に、 昭和 47 年に設立された。医の倫理に徹し、高度な臨床的実力を有する医師の養成㧍よび医学㧍よび看護学の進歩と福祉 の向上に資することが使命である。卒業生の多くは地域の総合医としての道を歩み始め、内科拈よび小児科と外科が主 な専攻科目となる。近々施行される専門医機構のプログラム制度は自治医科大学にとって試練である。執刀手術事例が 必要な外科系専門医プログラムでは、専門医習得の達成は困難である。卒業生が耳鼻咽喉科専門医プログラムを選択す ることも困難である。このような現状において、学生教育の歩むべき道は次のように考える。地域医療に必要な耳鼻咽 喉科診療技量と知識の習得に力を入れる学生教育を実践したい。BSLを通じ本学学生は日常診療に扔ける耳鼻咽喉科 の知識に基づく診療の重要性を認識している。この気持ちを失わずにいてもらいたい。そして医療に恵まれないへき地 等に扔ける医療の確保と向上㧍よび地域住民の福祉の増進につなげてもらいたい。自治医科大学は海外の多くの大学と 協定を結んでいる。学生交換と留学生を受け入れている。留学生の一部は帰国後責任ある立場に就任してきている。し かしアジア地域の医療と医学の物的および人的資源は限られ、必ずしも留学経験が生かされていない。今こそこれらア ジア地区の大学の医療と研究の向上に役立つ時期と考える。日本国内で培ったへき地等における医療の経験を生かし国 際協力を進めたい。

\section{研究の両輪}

臨床に携わる講座の研究としてトランスレーショナルリサーチを心がけている。各自が興味を持つ分野の日常の疑問 を研究テーマにしてもらいたい。研究結果から臨床に対する興味がさらに深まり、次の疑問につながる。幾つかの研究 から大きな発見が生まれることがある。長続きする研究からベーシックリサーチへ発展しても良い。いずれも「この分 野の研究は自分が引っ張るんだ!」とやりがいと自負を持って長く続く研究遂行に進んでもらいたい。講座の研究では トランスレーショナルリサーチとベーシックリサーチの両立が必要かつ重要である。次の世代につながっていく研究成 果を達成したい。

\section{当科の Issues}

社会より求められることは尊敬に值する人間性と高い診療レベルおよび高い倫理性である。世間より厳しい目で評価 されている。医育機関として是非とも達成しなくてはならない。さらに日本社会が今後迎える高齢者社会と財政困難に 備えなくてはならない。聴覚や嚥下状態の改善は人々の生活の質の向上に結びつくばかりではなく医療費削減に結びつ く。これからは効率の良い医学研究をしなくてはならない。iPs 細胞の技術を使用して疾患モデル細胞・組織を作成し 病態掞よび治療法を検討する予定である。癌治療では細胞毒性のある薬物治療から免疫療法に大きな転換期にさしかか っている。宿主の癌免疫に着目した新たな治療方法 oncolytic virus therapy を開発中である。当科の業績が将来評価さ れ、歴史に歩みが刻まれ、医療と医学の発展に貢献したい。 


\section{当然求められる資質}

人間性

・診療レベル

倫理
今後の高齢者社会に備える

－聴賞、嬩下

疾患モデル細胞・動物を作成

- 病態

治療方法

癌治療

- oncolytic virus therapy

免疫療法

医療福祉過疎地に貢献

・日本と海外

図 


\title{
明日の耳鼻咽喉科医療と医師を創る
}

\author{
羽藤 直人 \\ 愛媛大学医学系研究科 耳鼻咽喉科・頭頸部外科
}

\section{【はじめに】}

教授就任後 2 年が経過した今、改めて「夢と抱負」へ向き合う機会を与えていただき、まずは村上会長をはじめ関係 各位へ感謝申し上げます。本セミナーでは、私が愛媛大学耳鼻咽喉科・頭頸部外科で「夢の実現」に向け取り組んでい る活動の一端を紹介いたします。タイトルの「明日の耳鼻咽喉科医療と医師を創る」は、当教室のテーマとしてHPに も揭載しています。「明日の耳鼻咽喉科医療」として「顔面神経再生」と「人工中耳開発」を、さらに「明日の耳鼻咽 喉科医師」養成への試みを紹介したいと思います。なお、最高の医療には徹底した科学の裏付けが必要であり、研究、 特に臨床研究の推進が重要です。エビデンスに基づいた新たな治療法を開発し世界に発信することで、個人が直接治す より遥かに多くの患者さんに健康と幸せを提供することが可能です。教室員には広い視野、高い目線を持って、世界を 目指してもらいたいと思います。

\section{【明日の耳鼻咽喉科医療を創る】}

(1) 徐放化栄養因子を用いた顔面神経再生

線維芽細胞增殖因子（bFGF）は、強力な神経再生促進作用を有します。この bFGF を徐放化し、顔面神経麻疩の難 治例に局所投与をする臨床試験を、平成27年より開始しております。本治療の効果は、既にモルモットを用いた基礎研 究と臨床試験（第 II 相）で、有効性と安全性が確認されています。本研究では Bell 麻疩、Hunt 症候群の顔面神経高度 障害例を、(1)神経再生手術（減荷術＋徐放化 bFGF）、(2)従来法減荷術（減荷術＋ステロイド）、(3)保存治療（手術拒 否）の 3 群に分け、多施設共同の前向きランダム化比較試験（第正相）で治療効果を比較しています。神経再生手術の 有効性と安全性が実証されれば、世界にエビデンスを発信するとともに、徐放化ゼラチンの製品化、新規治療法として の確立を目指したいと考えています。

(2) 骨導人工中耳開発

1983年、世界に先駆け本邦で開発されたリオン社製の人工中耳は、広く普及するには至らず残念ながら 2005 年に製造 中止となりました。一方、スウェーデンで開発されたBAHA は欧米で普及が進み、骨導による聞こえの語音明瞭度が 良好なことが分かってきて打ります。そのほかにもCarina（米国)、MVS（オーストリア）、ACROS（韓国）等、海外 では人工中耳の開発競争が再燃していますが、これに後れを取らないようメイド・イン・ジャパンの埋め込み型骨導人 工中耳の開発に取り組んでいます。新型人工中耳の鍵は、圧電素子の約 1,000 倍の駆動力を持つ超磁歪素子にあります。 超磁歪素子は骨振動に十分なパワーと広い周波数応答性を有します。作製したプロトタイプの性能は優秀で、混合難聴 だけでなく感音難聴にも適応が拡大できると期待されます。これらの特徽はすべて革新的であり、既に国内および国際 特許を取得し、日本光電社との共同開発がスタートしています。

【明日の耳鼻咽喉科医師を創る】

教授就任後、最も重要視しているのは次世代を担う人造りです。「人が最大の資産」であることを念頭に、10年後、 20年後の耳鼻咽喉科医療に貢献可能な、後進の育成に向けた教育への取り組みを加速させたいと考えています。既に新 たな取り組みとして「愛媛 ENT 塾」を開設し、毎月エキスパートによる専攻医、研修医向けセミナーを始めていま

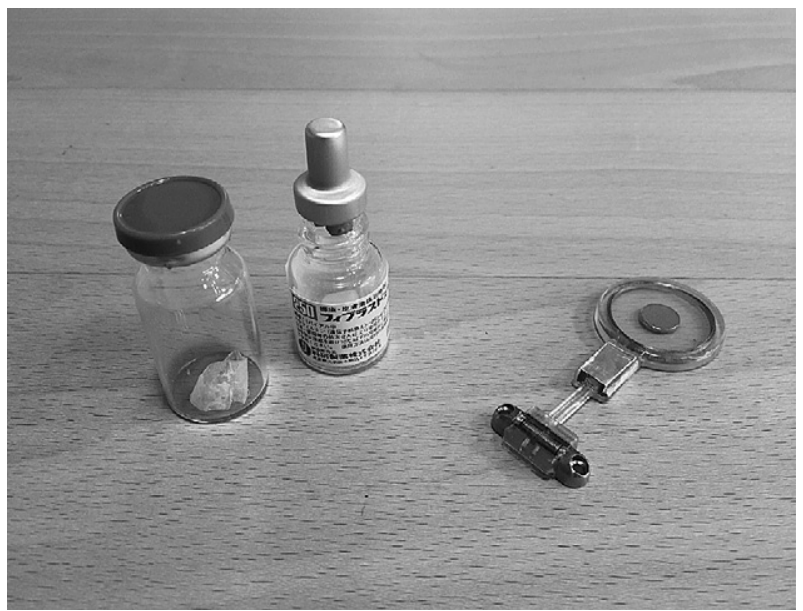

図 1 徐放化ゼラチンと bFGF および骨導人工中耳インプラント 


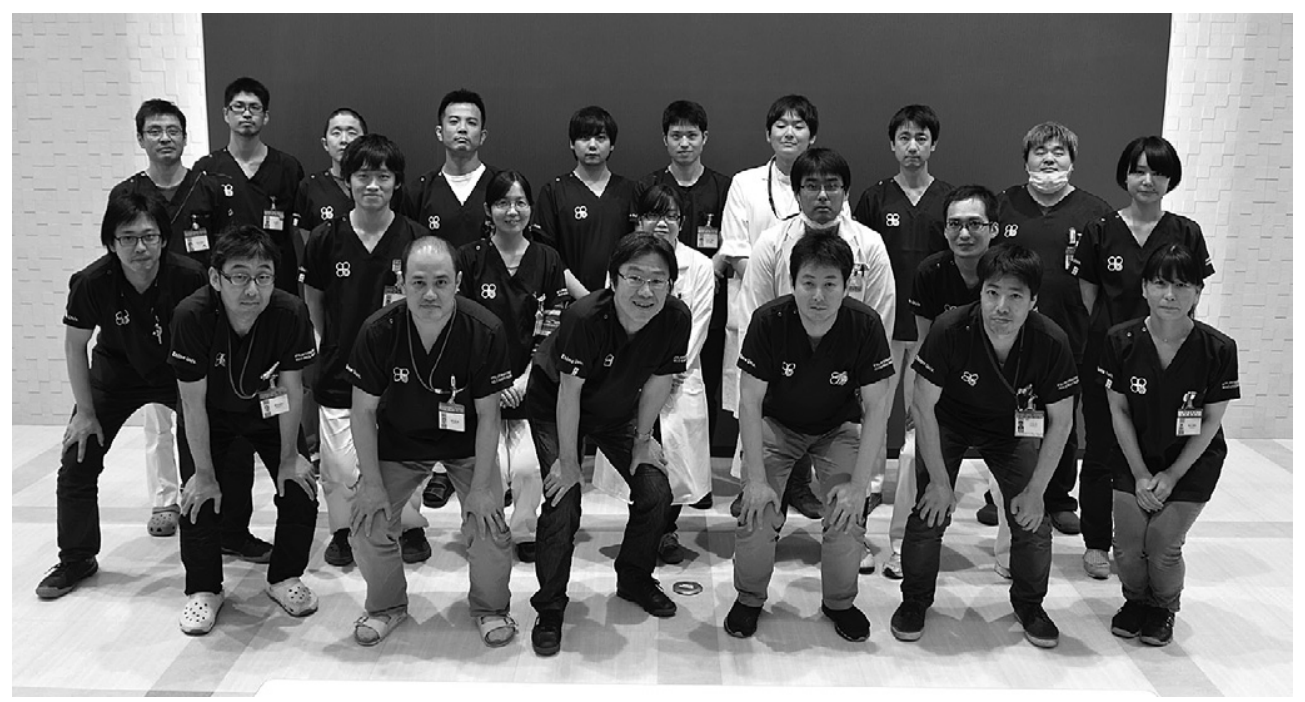

図 2 明日を創る愛媛大学教室員

す。また耳鼻科を選択した若手医師の多くは、できるだけ早く自分の手術技能を向上させたいと願っています。若手医 師に執刀の機会を与えながら手術を成功させるため、指導医に自己の能力向上と手術手技の簡略化、普遍化に努めても らっています。また、2009年からはご遺体を用いた手術研修の場である「愛媛耳鼻咽喉科臨床解剖セミナー」を設け、 研修医や若手医師の手術解剖のより深い理解と手技向上に注力しています。

愛媛の耳鼻咽喉科・頭頸部外科では、さらなる「地域医療のレベルアップ」と「最先端医療のレベルアップ」を両輪 として進めたいと考えています。地域の耳鼻咽喉科患者が安心して最高の医療を受けられる環境づくりには、優秀な担 い手の育成が重要です。それと共に、世界トップレベルの臨床能力を持った耳鼻咽喉科プロ集団を養成し、特に大学病 院での最高レベルの機能温存・再建手術の提供を目指しています。 